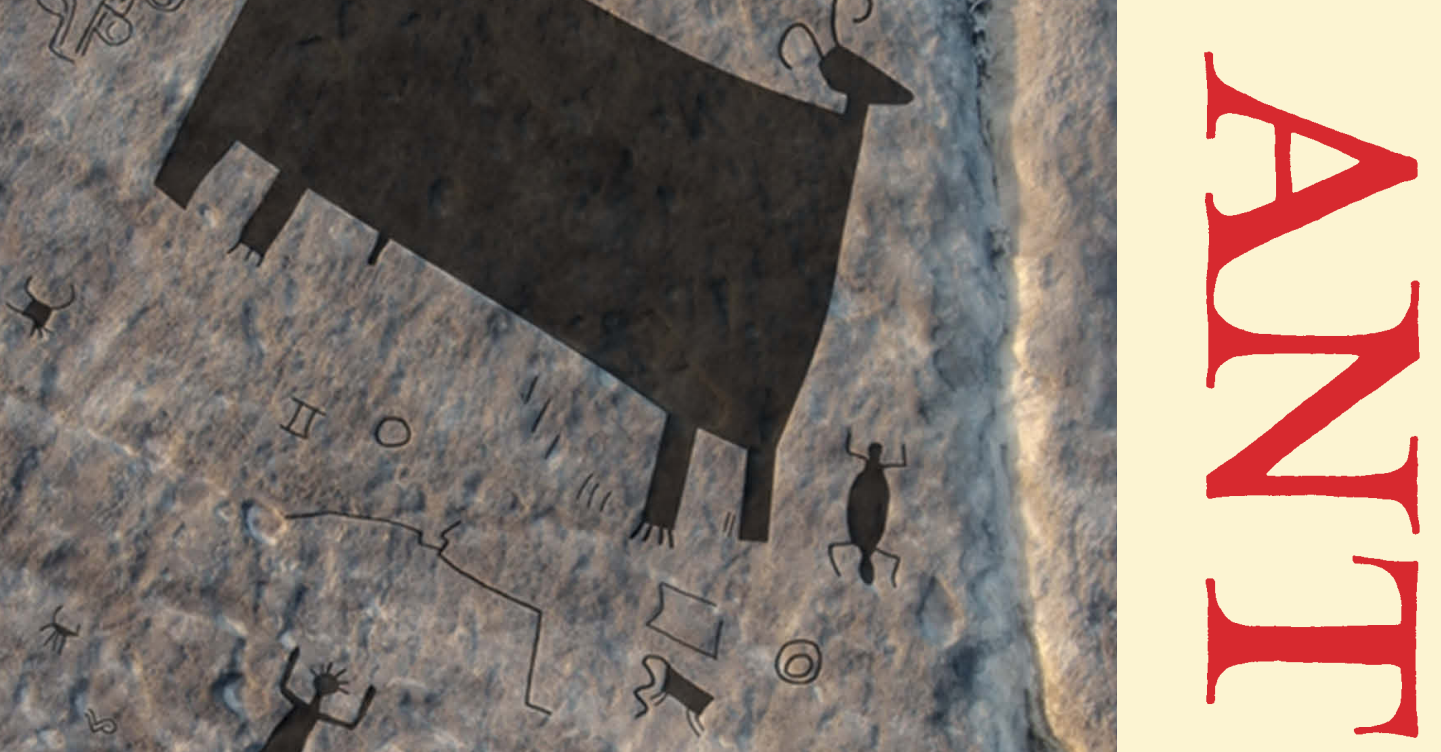

A.cose
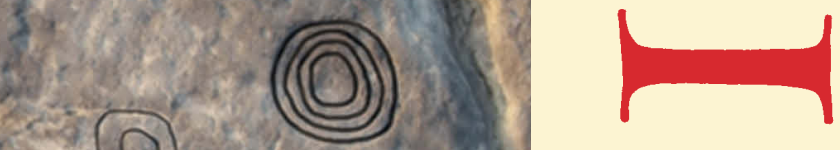

firingenes

( ) 2 है

(6)

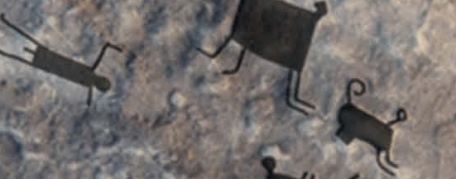

3

$40 x+\operatorname{cosin} x$

p:

sed ks
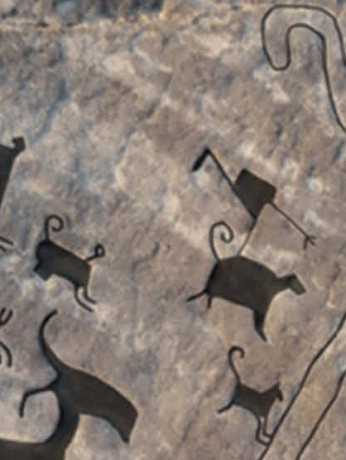

his

(a)

$\log ^{2} 3$

$\int_{4}^{4}$
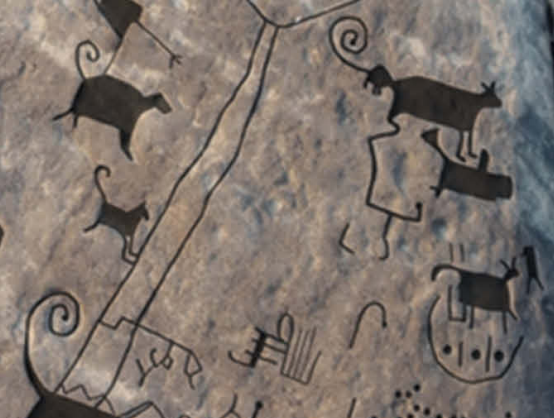

$\frac{1}{202}+125$

mates

(c)

श)

innsis

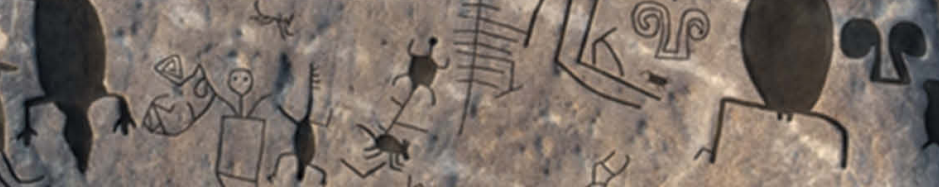

www.antiquity.ac.uk Volume 91 • Number 360 • December 2017

\title{
A REVIEW OF
}

\section{WORLD ARCHAEOLOGY}

EDITED BY CHRIS SCARRE

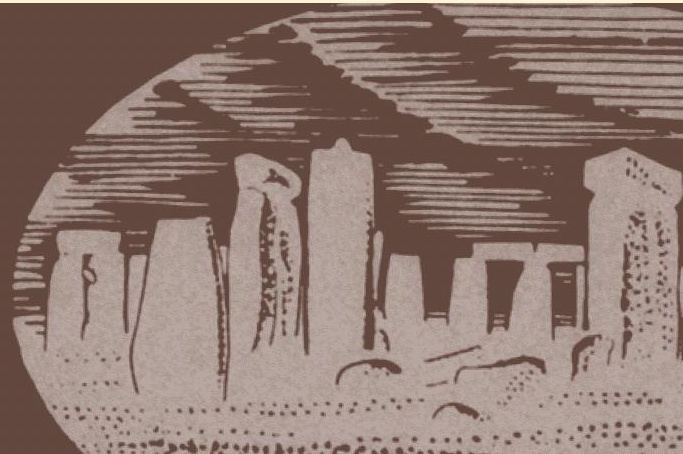


EDITOR

Chris Scarre

\section{REVIEWS EDITOR}

Robert Witcher

\section{EDITORIAL MANAGER}

Liz Ryan

\section{EDITORIAL Assistants}

Ross Kendall

Thomas Swindells

James Walker

\section{Media Assistant}

Tom Horne

\section{EDITORIAL ADDRESS}

Antiquity, Dept. of Archaeology,

Durham University, South Road, Durham DH1 3LE, UK

Tel: +44 (0) 191 3341125; Fax:+44 (0) 191 3341101; Email: editor@antiquity.ac.uk

Antiquity is an international peer-reviewed journal of archaeological research that aims to communicate the most significant discoveries, theory, method and cultural resource issues rapidly and in plain language to practising archaeologists everywhere.

Antiquity is included in the Cambridge Journals Online service at http://journals.cambridge.org/AQY. Additional content, the Project Gallery, and free-to-access material may be found at http://antiquity.ac.uk

Antiquity was founded in 1927 by O.G.S. Crawford and is owned by the Antiquity Trust, a registered charity. The trustees of the Antiquity Trust are Graeme Barker, Amy Bogaard, Robin Coningham, Barry Cunliffe, Roberta Gilchrist, Anthony Harding, Martin Millett, Nicky Milner, Stephanie Moser and Cameron Petrie.

The Directors of Antiquity Publications Ltd, owned by the Antiquity Trust and responsible for producing Antiquity are Chris Gosden, Sue Hamilton, Nicky Milner, Cameron Petrie, Mike Pitts, Chris Scarre and Marie Louise Sørensen.

\author{
Peter Bellwood, The Australian National University, Australia \\ Xingcan Chen, Chinese Academy of Social Sciences, Beijing \\ Eduardo Goés Neves, Universidade de São Paulo, Brazil \\ Elizabeth Graham, University College London, UK \\ Christine Hastorf, University of California Berkeley, USA \\ Charles Higham, University of Otago, New Zealand \\ Stephen Houston, Brown University, USA \\ Timothy Insoll, University of Exeter, UK \\ Susan Keech McIntosh, Rice University, USA \\ Ian Kuijt, University of Notre Dame, USA \\ Kevin Lane, Universidad de Buenos Aires, Argentina \\ Li Liu, Stanford University, USA \\ Akira Matsuda, University of Tokyo, Japan
}

EDITORIAL ADVISORY BOARD
Barbara Mills, University of Arizona, USA

Peter Mitchell, University of Oxford, UK

Timothy Pauketat, University of Illinois, USA

Victor Paz, University of The Philippines, The Philippines

Michael Petraglia, Max Planck Institute for the Science of

Human History, Jena, Germany

Innocent Pikirayi, University of Pretoria, South Africa

Susan Pollock, Freie Universität Berlin, Germany

Natalia Shishlina, State Historical Museum, Moscow, Russia

Benjamin Smith, University of Western Australia, Australia

Claire Smith, Flinders University, Australia

Monica Smith, University of California, Los Angeles, USA

Melinda Zeder, Smithsonian Institution, USA

Antiquity is published six times a year by Cambridge University Press for Antiquity Publications Ltd; February, April, June, August, October, December.

Advertising enquiries to the publisher at advertising@cambridge.org

(C)Antiquity Publications 2017. All rights reserved. No part of this publication may be reproduced, in any form or by any means, electronic, photocopying or otherwise, without permission in writing from Cambridge University Press. Permission to copy (for users in the USA) is available from Copyright Clearance Center, http://www.copyright.com, email: info@copyright.com.

This journal issue has been printed on FSCTM-certified paper and cover board. FSC is an independent, nongovernmental, not-for-profit organization established to promote the responsible management of the world's forests. Please see www.fsc.org for information.

Printed by Bell \& Bain Limited, Glasgow, UK.

Design: Barry Perks (www.yo-yo.uk.com)

Typesetting: Aptara Inc, New Delhi, India

Subscriptions can be purchased from Cambridge University Press and online at https://www.cambridge.org/core/journals/ antiquity/subscribe

Front cover: An aerial photograph of the eastern section of the main panel of engravings on Picture Island, located in the Atures Rapids, Venezuela. The panel contains at least 92 individual engravings, the largest of which are several metres across and recessed into the bedrock. The motifs documented here display similarities to several other rock art sites in the locality, as well as Brazil, Colombia, and much farther afield (C) Philip Riris, in this issue). 
ANT

Volume 91

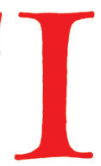

Q

Number 360

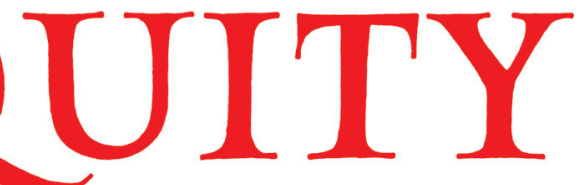

December 2017

\section{Editorial}

\section{Research}

A large handaxe from Wadi Dabsa and early hominin adaptations within the Arabian

Peninsula

Frederick W.F. Foulds, Andrew Shuttleworth, Anthony Sinclair, Abdullah M. Alsharekh, Saud Al Ghamdi, Robyn H. Inglis \& Geoff N. Bailey

The Kostënki 18 child burial and the cultural and funerary landscape of Mid Upper

Palaeolithic European Russia

Natasha Reynolds, Rob Dinnis, Alexander A. Bessudnov, Thibaut Devièse \& Thomas Higham

Fishing in life and death: Pleistocene fish-hooks from a burial context on Alor Island,

Indonesia

Sue O'Connor, Mahirta, Sofía C. Samper Carro, Stuart Hawkins, Shimona Kealy, Julien Louys \& Rachel Wood

Aurochs bone deposits at Kfar HaHoresh and the southern Levant across the agricultural transition

Jacqueline S. Meier, A. Nigel Goring-Morris \& Natalie D. Munro

Exploring the emergence of an 'Aquatic' Neolithic in the Russian Far East: organic residue analysis of early hunter-gatherer pottery from Sakhalin Island

Kevin Gibbs, Sven Isaksson, Oliver E. Craig, Alexandre Lucquin, Vyacheslav A. Grishchenko, Tom F.G. Farrell, Anu Thompson, Hirofumi Kato, Alexander A. Vasilevski \& Peter D. Jordan

Spiralled patchwork in pottery manufacture and the introduction of farming to Southern Europe

Louise Gomart, Allon Weiner, Marzia Gabriele, Gilles Durrenmath, Sabine Sorin, Lucia Angeli, Marta Colombo, Cristina Fabbri, Roberto Maggi, Chiara Panelli, Didier F. Pisani, Giovanna Radi, Carlo Tozzi \& Didier Binder

Understanding blunt force trauma and violence in Neolithic Europe: the first experiments using a skin-skull-brain model and the Thames Beater Meaghan Dyer \& Linda Fibiger

Armies in the Early Bronze Age? An alternative interpretation of Únětice Culture axe hoards Harald Meller

Disproving claims for small-bodied humans in the Palauan archipelago Jessica H. Stone, Scott M. Fitzpatrick \& Matthew F. Napolitano 
Cereal cultivation and nomad-sedentary interactions at the Late Bronze Age 1561 settlement of Zawiyet Umm el-Rakham

Nicky Nielsen

Revisiting lead isotope data in Shang and Western Zhou bronzes

Zhengyao Jin, Ruiliang Liu, Jessica Rawson \& A. Mark Pollard

Exotica as prestige technology: the production of luxury gold in Western Han society

Yan Liu

On confluence and contestation in the Orinoco interaction sphere: the engraved rock art of the Atures Rapids

Philip Riris

Beneath the Basilica of San Marco: new light on the origins of Venice

Albert J. Ammerman, Charlotte L. Pearson, Peter I. Kuniholm, Bruce Selleck \&

Ettore Vio

Reverential abandonment: a termination ritual at the ancient Maya polity of

El Palmar

Kenichiro Tsukamoto

\section{Debate}

Franklin's fate: discoveries and prospects

N. James

\section{Book Reviews}

\section{Review articles}

Theory and practice in Russian and Soviet archaeology: retrospect and prospect YAROSLAV V. KUZMIN

A Russian perspective on theoretical archaeology: the life and work of Leo S. Klejn Stephen Leach

Istoriya rossiiskoi arkheologii: ucheniya, shkoly i lichnosti [The history of Russian archaeology: doctrines, schools and personalities] L.S. Klejn

Bioarchaeological perspectives on the social experience of prehistoric and historic communities

KATHRYN M. BAUSTIAN

Bones of complexity: bioarchaeological case studies of social organization and skeletal biology Haagen D. Klaus, Amanda R. Harvey \& Mark N. Cohen (ed.)

Colonized bodies, worlds transformed: toward a global bioarchaeology of contact and colonialism Melissa S. Murphy \& Haagen D. Klaus

\section{Ancient Rome mapped}

BERNARD FRISCHER

The atlas of ancient Rome: biography and portraits of the city. Volume 1: text and images; volume 2: tables and indexes Andrea Carandini (ed.)

Aztec political economy: a new conceptual frame 
The Aztec economic world: merchants and markets in ancient Mesoamerica Kenneth G. Hirth

Rethinking the Aztec economy Deborah L. Nichols, Frances F. Berdan \& Michael E. Smith (ed.)

The Oxford handbook of the Aztecs Deborah L. Nichols \& Enrique Rodríguez-Alegría (ed.)

\section{Book reviews}

W. Roger Powers, R. Dale Guthrie \& John F. Hoffecker (edited by Ted Goebel) Dry Creek: archaeology and paleoecology of a Late Pleistocene Alaskan hunting camp

DAVID J. MELTZER

Pierre Pétrequin, Estelle Gauthier \& Anne-Marie Pétrequin JADE: interprétations sociales des objets-signes en jades alpins dans l'Europe néolithique. Tomes $3 \& 4$

Carlos P. Odriozola, José Ángel Garrido Cordero \& Rodrigo Villalobos GARCÍA

H. Fokkens, B.J.W. Steffens \& S.F.M van As Farmers, fishers, fowlers, hunters: knowledge generated by development-led archaeology about the Late Neolithic, the Early Bronze Age and the start of the Middle Bronze Age (2850-1500 cal BC) in the Netherlands CHRISTOPHER EVANS

C. Carreras \& J. van den Berg (ed.) Amphorae from the Kops Plateau (Nijmegen) STEVEN WILLIS

Jan Schneider Ländliche Siedlungsstrukturen im römischen Spanien. Das Becken von Vera und das Camp de Tarragon—zwei Mikroregionen im Vergleich

THOMAS SCHIERL

Elizabeth Fentress, Caroline Goodson, Marco Maiuro, Margaret Andrews \& J. Andrew Dufton (ed.) Villa Magna: an imperial estate and its legacies: excavations 2006-10 R.J.A. WILSON

Martha Sharp Joukowsky Petra Great Temple volume 3: Brown University excavations 1993-2008, architecture and material culture

RUBINA RAJA

Manfred K.H. Eggert \& Dirk Seidensticker Campo: archaeological research at the mouth of the Ntem River (south Cameroon)

ANNE HaOUR

Michela Gaudiello \& Paul A. Yule (ed.) Mifsas Bahri: a Late Aksumite frontier community in the mountains of southern Tigray. Survey, excavation and analysis, 2013-16 RODOLFO FATTOVICH

Bjarne Grønnow The frozen Saqqaq sites of Disko Bay, West Greenland. Qeqertasussuk and Qajaa (2400-900 BC)

T. MAX FRIESEN

\section{New Book Chronicle}

Robert Witcher 


\section{Project Gallery on the website (http://www.cambridge.org/core/journals/antiquity/ project-gallery)}

Ushbulak-1: new Initial Upper Palaeolithic evidence from Central Asia

Mikhail Shunkov, Anton Anoikin, Zhaken Taimagambetov, Konstantin Pavlenok, Vladimir Kharevich, Maxim Kozlikin \& Galina Pavlenok

A Late Palaeolithic assemblage at Kunjaram, south-east India

Malavika Chatterjee, Kumar Akhilesh, Shanti Pappu, Sudha Ravindranath \& Udayaraj

New investigations of the Epipalaeolithic in western Central Asia: Obishir-5

Svetlana V. Shnaider, Maciej T. Krajcarz, T. Bence Viola, Aida Abdykanova, Ksenia A. Kolobova, Alexander Yu. Fedorchenko, Saltanat Alisher-kyzy \& Andrei I. Krivoshapkin

A new Later Upper Palaeolithic open-air site with articulated horse bone in the Colne Valley, Berkshire

Alistair Barclay, Silvia Bello, Philippa Bradley, Phil Harding, Lorrain Higbee, Andrew Manning, John Powell, Richard Macphail, Alison Roberts, Mark Stewart \& Nick Barton

New archaeological investigations at the Lothagam harpoon site at Lake Turkana Steven Goldstein, Elisabeth Hildebrand, Michael Storozum, Elizabeth Sawchuk, Jason Lewis, Cecilia Ngugi \& Lawrence H. Robbins 